ББК 63.4

$$
\begin{gathered}
\text { Организация конференции и издание материалов проведены } \\
\text { при финансовой поддержке Российского фонда фундаментальных исследований, } \\
\text { проект № 19-09-20008 }
\end{gathered}
$$

Утверждено к печати Ученым советом ИИМК РАН

Редакционная коллегия тома II: А. В. Поляков, Е. С. Ткач (отв. редакторы), М. Т. Кашуба, Л. Б. Кирчо, Е. А. Черлёнок, В. Я. Стёганцева, А. И. Климушина

Рещензенты: д. и. н. Л. Б. Вишняцкий, д. и. н. А. А. Выборнов

Программный комитет конференции: академик РАН, д. и. н., проф. М. Б. Пиотровский (Государственный Эрмитаж, почетный председатель); д. и. н. В. А. Лапшин (ИИМК РАН, председатель); д. и. н. А. В. Головнёв (МАЭ РАН, сопредседатель); д. и. н. В. А. Дергачёв (Высшая антропологическая школа, Молдова, сопредседатель); д. и. н. И. Ф. Попова (ИВР РАН, сопредседатель); академик АН Республики Узбекистан, д. и. н., проф. Э. В. Ртвеладзе (сопредседатель); к. и. н. А. В. Поляков (ИИМК РАН, зам. председателя); к. и. н. В. А. Алёкшин (ИИМК РАН, зам. председателя); д. и. н. Ю. Е. Берёзкин (МАЭ РАН); Dr., Prof. Н. Бороффка

(Германский археологический институт, Германия); В. С. Бочкарёв (ИИМК РАН);

Dr. Э. Кайзер (Свободный университет Берлина, Германия); к. и. н. М. Т. Кашуба (ИИМК РАН); д. и. н. Л. Б. Кирчо (ИИМК РАН); к. и. н. А. В. Кияшко (Южный федеральный университет); к. и. н. П. Ф. Кузнецов (СГСПУ); к. и. н. Н. М. Малов (СНИГУ); к. и. н. В. П. Никоноров (ИИМК РАН); Ю. Ю. Пиотровский (Государственный Эрмитаж); д. и. н., проф. Д. Г. Савинов (Институт истории СПбГУ); к. и. н. В. Н. Седых (Институт истории СПбГУ); к. и. н. Н. Н. Скакун (ИИМК РАН); к. и. н. Н. Ф. Соловьёва (ИИМК РАН); к. и. н. А. И. Торгоев (Государственный Эрмитаж); к. и. н. Е. А. Черлёнок (Институт истории СПбГУ)

Организационный комитет конференции: к. и. н. А. В. Поляков (ИИМК РАН, председатель); к. и. н. В. А. Алёкшин (ИИМК РАН, зам. председателя); В. С. Бочкарёв (ИИМК РАН); к. и. н. М. Т. Кашуба (ИИМК РАН); д. и. н. Л. Б. Кирчо (ИИМК РАН);

А. И. Климушина (ИИМК РАН, отв. секретарь); к. и. н. В. П. Никоноров (ИИМК РАН); Ю. Ю. Пиотровский (Государственный Эрмитаж); В. Я. Стеганцева (ИИМК РАН); В. В. Терёхина (ИИМК РАН, МАЭ РАН, отв. секретарь); к. и. н. Е. С. Ткач (ИИМК РАН); И. Ж. Тутаева (Государственный Эрмитаж); к. и. н. Е. А. Черлёнок (Институт истории СПбГУ)

Древности Восточной Европы, Центральной Азии и Южной Сибири в контексте связей и взаимодействий в евразийском культурном пространстве (новые данные и концепции): Материалы Международной конференции, 18-22 ноября 2019 г., Санкт-Петербург. Т. ІІ. Связи, контакты и взаимодействия древних культур Северной Евразии и цивилизаций Востока в эпоху палеометалла (IV-I тыс. до н. э.). К 80-летию со дня рождения выдающегося археолога В. С. Бочкарёва. - СПб.: ИИМК РАН, Невская Типография, 2019. - 287 с.

ISBN 978-5-907053-35-9

DOI 10.31600/978-5-907053-35-9 


\title{
Литература
}

Бочкарёв В. С. 2017. Этапы развития металлопроизводства эпохи поздней бронзы на Юге Восточной Европы // Stratum plus. № 2. С. 159-204.

Дергачёв В. А. 1997. Металлические изделия. К проблеме генезиса культур раннего гальштата Карпато-Данубио-Нордпонтийского региона. Кишинёв.

Дергачёв В. А. 2010. Топоры-кельты поздней бронзы Карпато-Подунавья. Вып. 1. Одноушковые кельты с арковидными фасками. Кишинёв.

Дело о древних медных предметах, найденных в с. Сосновке, Чигиринского у., Киевской губ. // НА ИИМК РАН. РО. Ф. 1. Д. 104/1896.

Отчет ИАК за 1896 год. 1898. СПб.

Черных Е. Н. 1976. Древняя металлообработка на юго-западе СССР. М.

Tallgren A. M. 1926. La Pontide préscythique après l'introduction des métaux. Helsinki (Eurasia Septentrionalis Antiqua. T. 2).

\section{HOARD OF THE LATE BRONZE AGE FROM THE VILLAGE OF SOSNOVKA}

\section{Indira Zh. Tutayeva}

The State Hermitage Museum, St. Petersburg, Russia

Keywords: hoard, Late Bronze Age, Middle Dnieper region.

In 1896, several bronze objects were found near the village of Sosnovka, Chigirinsky Uyezd, Kiev Province. The Sosnovka hoard consisted of four celts and six bronze bars. The hoard had not been attracting the interest of scholars for a long time. Meanwhile, the fact that objects of this kind were found in the Middle Dnieper region induces certain valuable reflections. It was therefore decided to publish comprehensively the items from Sosnovka as a separate study. As a result, the hoard could have been attributed to the Late Bronze Age. Its chronology and cultural belonging were defined and also the importance of such findings in the Middle Dnieper region was highlighted.

\section{ЭЛЕМЕНТНЫЙ СОСТАВ ИЗДЕЛИЙ КЛАДА СОСНОВАЯ МАЗА ЭПОХИ ПОЗДНЕЙ БРОНЗЫ ${ }^{1}$}

\author{
В. М. Ретивов ${ }^{\star}$, А. Ю. Лобода ${ }^{\star}$ Е. Ю. Терещенко ${ }^{\star}$, И. А. Каменских ${ }^{\star *}$, \\ Н. И. Шишлина ${ }^{* * *}$ \\ ${ }^{*}$ НИЦ «Курчатовский институт», Москва, Россия; ${ }^{* *}$ Московский государственный \\ университет им. М. В. Ломоносова, Москва, Россия; ${ }^{* * *}$ Государственный исторический \\ музей, Москва, Россия
}

DOI: 10.31600/978-5-907053-35-9-192-194

Ключевые слова: клад Сосновая Маза, элементный анализ, масс-спектрометрия с индуктивно-связанной плазмой, МС-ИСП.

Клад у с. Сосновая Маза найден в 1901 г. в Хвалынском р-не Саратовской обл. Коллекция Исторического музея состоит из 68 предметов из бронзы, общий вес клада - примерно 21 кг (ГИМ, № 43959, оп. А307/1-68). Незначительная часть коллекция хранится в Саратовском областном музее краеведения и в Хвалынском музее.

Самые первые исследования металла изделий Сосново-Мазинского клада приведены в работе А. А. Спицына (Спицын 1909: 66). Несколько предметов клада были проанализированы

\footnotetext{
${ }^{1}$ Работа выполнена при финансовой поддержке РФФИ, проект ОФИ-м 17-29-04176.
} 
Д. А. Сабанеевым, который, помимо меди, обнаружил в их составе железо (0,2-8,3\%), а в одном серпе - незначительные следы мышьяка. Позднее, предметы клада изучались И. Р. Селимхановым (Черных 1966: 124), который также указывал на значительное присутствие железа в сплавах. Наиболее детально элементный состав предметов Сосново-Мазинского клада был изучен Е. Н. Черных, который в 1966 г. исследовал 63 изделия клада в лаборатории спектрального анализа ИА АН СССР. Он также отметил необычный состав предметов, в которых обнаружил «до 5 \% железа <..> никель, кобальт, мышьяк - до десятых долей <..> свинец, олово, серебро и цинк - до сотых долей», в некоторых случаях был зафиксирован марганец (Черных 1966: 124). Е. Н. Черных связывал состав изделий клада с началом выплавки металла из медно-колчеданных руд (халькопирит), сопутствующим минералом которых является железный колчедан (пирит). Он также упомянул, что из аналогичного сплава был сделан и косарь, найденный на Алексеевском поселении (Там же: 128). Отметим, что Сосново-Мазинский клад изучался как комплекс однородных изделий, без указания музейных номеров предметов, что затрудняло проведение корреляции между типом изделия и его составом.

Новый проект по исследованию Сосново-Мазинского клада включает комплекс работ по индивидуальному изучению каждого предмета по разработанному алгоритму: трасологический анализ, определение фазового и элементного состава металла. В данной работе представлен анализ элементного состава предметов методом масс-спектрометрии с индуктивно связанной плазмой (МС-ИСП). Измерения выполнялись на приборе Elan DRC-e c ПО ElanVersion 3.4 Hotfix 1 (Лобода и др. 2018). Было изучено 57 предметов из собрания Исторического музея и три предмета из коллекции Саратовского областного музея краеведения. В сопоставительную выборку вошли серпы и ножи из памятников Приуралья и Казахстана эпохи поздней бронзы.

В составе изделий Сосново-Мазинского клада основными компонентами сплава во всех случаях, как и было определено ранее, являются медь (Cu: 91,30-99,19\%) и железо (Fe: 0,027,85 \%). Также обнаружены микропримеси $\mathrm{Ni}, \mathrm{Zn}, \mathrm{As}, \mathrm{Co}$, Se;и следовые примеси $\mathrm{Na}, \mathrm{Mg}, \mathrm{Al}, \mathrm{Si}$, $\mathrm{Ca}, \mathrm{V}, \mathrm{Mo}, \mathrm{Rh}, \mathrm{Ag}, \mathrm{Sn}, \mathrm{Sb}, \mathrm{Pt}, \mathrm{Pb}, \mathrm{Cr}, \mathrm{B}$. Статистическая обработка данных МС-ИСП позволила выявить два вида прямых корреляций элементов в составе сплавов: $\mathrm{Ni}, \mathrm{Zn}-\mathrm{Fe} ; \mathrm{As}-\mathrm{Cu}$.

Сравнительный анализ сплавов сопоставительных образцов показал, что наиболее близкий состав к сосново-мазинским изделиям у серпа из Алексеевской стоянки в Казахстане (Fe: 1,4\%; следовые примеси Co, Ni, Zn, As, Se, Ag), в то время как изделия из поселения рудокопов Михайло-Овсянка в Среднем Поволжье значительно отличаются от них (Fe: 0-0,1 \%, микропримесь Ag и следовые примеси $\mathrm{Co}, \mathrm{Ni}, \mathrm{Zn}, \mathrm{As}, \mathrm{Se}, \mathrm{Sn}$ ).

Отметим, что помимо возможной связи железосодержащих медных сплавов с выплавкой меди из медного колчедана, цинк, кобальт и никель в составе металла (Минералогическое исследование... 1960) могут также указывать, что металл, из которого изготовили изделия Сосново-Мазинского клада, был выплавлен из медных песчаников.

\section{Литература}

Лобода А. Ю., Терещенко Е. Ю., Антипенко А. В., Ретивов В. М., Пресняков М. Ю., Колобылина Н. Н., Кондратьев О. А., Шишлина Н. И., Яцишина Е. Б., Кашкаров П. К. 2018. Методы определения элементного состава металла археологических объектов при коррозионных наслоениях и в ограниченных условиях пробоотбора материала // Поволжская археология. № 4 (26). С. 203-221.

Минералогическое исследование руд цветных и редких металлов. 1960 / Ли А. Ф. (ред). М. Спицын А. А. 1909. Некоторые находки медного века // Известия ИАК. СПб. Вып. 29. С. 65-67.

Черных Е. Н. 1966. О химическом составе металла клада из Сосновой Мазы // КСИА. Вып. 108. С. 123-131. 


\title{
ELEMENTAL COMPOSITION OF THE TOOLS FROM THE SOSNOVAYA MAZA HOARD OF THE LATE BRONZE AGE
}

Vasiliy M. Retivov*, Anastasiya Yu. Loboda ${ }^{\star}$, Elena Yu. Tereshchenko*, Irina A. Kamenskikh ${ }^{\star \star}$, Natal'ya I. Shishlina ${ }^{* *}$

${ }^{*}$ Kurchatov Institute, Moscow, Russia; ${ }^{* *}$ Moscow State University, Moscow, Russia;

*** State Historical museum, Moscow, Russia

Keywords: Sosnovaya Maza hoard, elemental analysis, inductively coupled plasma mass spectrometry, MS-ICP.

The elemental composition of the sickles from the Sosnovaya Maza hoard was studied using inductively coupled plasma mass spectrometry (MS-ICP). The analysis of the composition was conducted on 57 specimens from the collection of the State Historical Museum and 3 items from the collection of the Saratov Regional Museum of Local History. Reference samples included sickles and knives from Late Bronze Age sites of the Urals and Kazakhstan. The main components of the alloys of the Sosnovaya Maza hoard specimens are copper (91.30-99.19\%) and iron (0.02-7.85\%). Also, in the alloys there were micro- and trace impurities of the following elements: $\mathrm{Ni}, \mathrm{Zn}, \mathrm{As}, \mathrm{Pb}, \mathrm{Co}$, and Se. Statistical processing of the MS-ICP results made it possible to identify two types of direct correlations between the contents of individual alloy components over the entire assemblage studied. Investigation of alloys of the reference samples showed that the closest composition to the Sosnovaya Maza items is demonstrated by the sickle from the Alekseyevka site in Kazakhstan.

\section{ТРАСОЛОГИЧЕСКОЕ ИССЛЕДОВАНИЕ «СЕРПОВ» ИЗ КЛАДА СОСНОВАЯ МАЗА}

\author{
А. Ю. Лобода ${ }^{\star}$, Н. Н. Шишлина ${ }^{\star *}$ \\ ${ }^{\star}$ НИЦ «Курчатовский институт», Москва, Россия; ${ }^{*}$ Государственный исторический \\ музей, Москва, Россия
}

DOI: 10.31600/978-5-907053-35-9-194-196

Ключевые слова: клад Сосновая Маза, трасологический анализ.

Исследуемый клад был найден в 1901 г. в Хвалынском р-не Саратовской обл. В коллекции Государственного исторического музея хранится 68 изделий клада. Два серпа и кельт хранятся в Саратовском областном музее краеведения (СОМК), один серп и кинжал находятся в Хвалынском музее.

Исследованием орудий, входящих в состав Сосново-Мазинского клада, в разное время занимались Н. А. Аванесова (1991), В. А. Дергачёв и В. С. Бочкарёв (2002), элементный состав изделий изучался Е. Н. Черных (1966).

В данной работе представлены результаты трасологического исследования 42 серпов из коллекции ГИМ и двух серпов из собрания СОМК. В литературе орудия такого типа известны как «косари-серпы сосново-мазинского типа». Это широкое однолезвийное орудие с изогнутым обухом с бортом и прямым лезвием. Пятка четырехугольной формы, как правило, не выделена, в центре - округлое отверстие или штырь.

Трасологический анализ серпов выявил ряд следов на поверхности предметов, которые были отнесены к трем технологическим этапам. Литейные дефекты (каверны, наросты, пористость) относятся к этапу изготовления изделий. Проковка лезвия, облоя и литейных дефектов, шлифовка лезвия - к следам постлитейной обработки. Также была выявлена третья группа следов, отражающая вероятное использование серпов, - зарубки на лезвиях, трещины, в одном случае - следы незаконченного намеренного разрубания серпа, возможно, для вторичного использования. 